\title{
Thermal behaviour of hydroxides, hydroxysalts and hydrotalcites
}

\author{
PARTHASARATHI BERA, MICHAEL RAJAMATHI ${ }^{\dagger}$, M S HEGDE and \\ P VISHNU KAMATH ${ }^{\dagger *}$ \\ Solid State and Structural Chemistry Unit, Indian Institute of Science, Bangalore 560 012, India \\ ${ }^{\dagger}$ Department of Chemistry, Central College, Bangalore University, Bangalore 560 001, India
}

MS received 27 December 1999

\begin{abstract}
Mass spectrometric analysis of gases evolved during thermal decomposition of divalent metal hydroxides, hydroxysalts and hydrotalcites show that all these compounds undergo dehydration in the temperature range $30<T<220^{\circ} \mathrm{C}$ followed by decomposition at temperatures above $250^{\circ} \mathrm{C}$. The latter step involves simultaneous deanation and dehydroxylation of the layers. Our observations conclusively prove that alternative mechanisms which envisage $\mathrm{CO}_{2}$ evolution due to deanation at lower temperatures proposed by Kanezaki to be wrong.
\end{abstract}

Keywords. Hydroxides; hydrotalcites; temperature programmed decomposition (TPD).

\section{Introduction}

Hydroxides $\left[\mathrm{M}(\mathrm{OH})_{2}\right]$, hydroxysalts $\left[\mathrm{M}(\mathrm{OH})_{2-x}\left(\mathrm{~A}^{n-}\right)_{x / n} \cdot m \mathrm{H}_{2} \mathrm{O}\right.$, where $x=0.5-1 \cdot 0]$ and hydrotalcite-like layered double hydroxides $\left[\mathrm{M}_{1-x}^{\mathrm{II}} \mathrm{M}_{x}^{\prime \text { III }}(\mathrm{OH})_{2}\left(\mathrm{~A}^{n-}\right)_{x / n} \cdot m \mathrm{H}_{2} \mathrm{O}\right.$, where $\mathrm{M}^{\mathrm{II}}=$ $\mathrm{Mg}, \mathrm{Co}, \mathrm{Ni}, \mathrm{Cu}, \mathrm{Zn}$ or $\mathrm{Cd}, \mathrm{M}^{\mathrm{III}}=\mathrm{Al}, \mathrm{V}, \mathrm{Cr}, \mathrm{Fe}$ or $\mathrm{Ga}$ and $x=0 \cdot 25-0 \cdot 33$ ] derive their structures from that of mineral brucite, $\left[\mathrm{Mg}(\mathrm{OH})_{2}\right]$. In brucite, $\mathrm{OH}^{-}$ions are hexagonally close packed and $\mathrm{Mg}^{2+}$ ions occupy alternate layers of octahedral sites resulting in a stacking of charge-neutral layers of the composition $\left[\mathrm{Mg}(\mathrm{OH})_{2}\right](\overline{P 3} m 1, a=3.01 \AA$ and $c=4.8 \AA$ ) (Oswald and Asper 1977).

While the $\beta$-hydroxides of nickel and cobalt are isostructural with brucite, in the $\alpha$-hydroxides, a fraction, $x$, of the hydroxyl ions are protonated leading to positively charged layers of the composition $\left[\mathrm{M}(\mathrm{OH})_{2-x}\right.$ $\left.\left(\mathrm{H}_{2} \mathrm{O}\right)_{x}\right]^{x+}$. Anions and water molecules are incorporated in the interlayer region for charge balance and stability leading to an increased interlayer spacing $(c / 3=7.6 \AA$ when the anion is $\mathrm{CO}_{3}{ }^{2-}$ ) (Kamath et al 1997).

When a fraction, $x$, of the hydroxyl ions of the brucite layer is replaced by anions, the layer composition becomes $\left[\mathrm{M}(\mathrm{OH})_{2-x}\left(\mathrm{~A}^{n-}\right)_{x / n}\right]$. Here the anions are grafted to the metal ions and such materials are referred to as hydroxysalts (Gallezot and Prettre 1969). Water molecules may be incorporated in the interlayer region for stability.

In hydrotalcite-like layered double hydroxides, a fraction, $x$, of the $\mathrm{M}^{2+}$ ions of the brucite layers are isomorphously substituted by $\mathbf{M}^{\prime 3+}$ ions to give the layer composition $\left[\mathrm{M}_{1-x}^{\mathrm{II}} \mathrm{M}_{x}^{\prime \mathrm{III}}(\mathrm{OH})_{2}\right]^{x+}$. Anions and water mole-

\footnotetext{
*Author for correspondence
}

cules are incorporated in the interlayer region (Cavani et al 1991).

These hydroxide materials are used as precursors for oxide catalysts (Baird et al 1997) and the catalytic activity of the oxide catalysts depends on the structure, composition, morphology and thermal history of the precursor. It is, therefore, important to understand the structural and compositional changes that occur during the hydroxide decomposition. Considerable work has been done to understand the thermal behaviour of hydroxide based materials (Cavani et al 1991).

Most hydroxide materials considered here yield oxides on thermal decomposition above $500^{\circ} \mathrm{C}$. While the hydroxides and hydroxysalts yield the corresponding metal oxides, the hydrotalcites yield a mixture of the divalent metal oxide $\left(\mathrm{M}^{\mathrm{II}} \mathrm{O}\right)$ and the mixed metal spinel $\left(\mathrm{M}^{\mathrm{II}} \mathrm{M}^{\prime \mathrm{III}} \mathrm{O}_{4}\right)$. The hydroxide to oxide conversion has been extensively studied by thermogravimetry and involves a number of competing reactions such as dehydration, deanation of the interlayer region and dehydroxylation of the brucite slabs. These processes may occur in separate or combined steps. It is generally believed that dehydration precedes the deanation-dehydroxylation step. However, there is no direct evolved gas analysis data as evidence to support this belief. In many systems one or more of these steps can be reversed either by simply cooling (Puttaswamy and Kamath 1997) or by treating the oxide residue in water (Sato et al 1986). Reversible thermal behaviour has been established both by weight gain data as well as by variable temperature X-ray powder diffraction (Constantino and Pinnavaia 1995).

Considerable confusion regarding our understanding of the thermal behaviour of hydroxide materials was created by a recent series of papers by Kanezaki (1998a-d), who 
proposed that deanation precedes dehydration by a novel chemical reaction between the intercalated anions and water molecules, thus eliminating the dehydration step entirely. While the generally accepted mechanism for the decomposition of carbonate containing $\mathrm{Mg}-\mathrm{Al}$ hydrotalcite is

$$
\begin{aligned}
& \mathrm{Mg}_{1-x} \mathrm{Al}_{x}(\mathrm{OH})_{2}\left(\mathrm{CO}_{3}\right)_{x / 2} \cdot m \mathrm{H}_{2} \mathrm{O} \stackrel{25-200^{\circ} \mathrm{C}}{\longrightarrow} \\
& \mathrm{Mg}_{1-x} \mathrm{Al}_{x}(\mathrm{OH})_{2}\left(\mathrm{CO}_{3}\right)_{x / 2} \stackrel{225-500^{\circ} \mathrm{C}}{\longrightarrow} \\
& x / 2 \mathrm{MgAl}_{2} \mathrm{O}_{4}+(1-3 x / 2) \mathrm{MgO},
\end{aligned}
$$

Kanezaki proposed that the decomposition takes place as

$$
\begin{aligned}
& \mathrm{Mg}_{1-x} \mathrm{Al}_{x}(\mathrm{OH})_{2}\left(\mathrm{CO}_{3}\right)_{x / 2} \cdot m \mathrm{H}_{2} \mathrm{O} \stackrel{25-200^{\circ} \mathrm{C}}{\longrightarrow} \\
& \mathrm{Mg}_{1-x} \mathrm{Al}_{x}(\mathrm{OH})_{2+x} \cdot y \mathrm{H}_{2} \mathrm{O} \stackrel{225-500^{\circ} \mathrm{C}}{\longrightarrow} x / 2 \mathrm{MgAl}_{2} \mathrm{O}_{4}
\end{aligned}
$$$$
\text { (Kanezaki phase II) }
$$$$
+(1-3 x / 2) \mathrm{MgO} \text {, }
$$

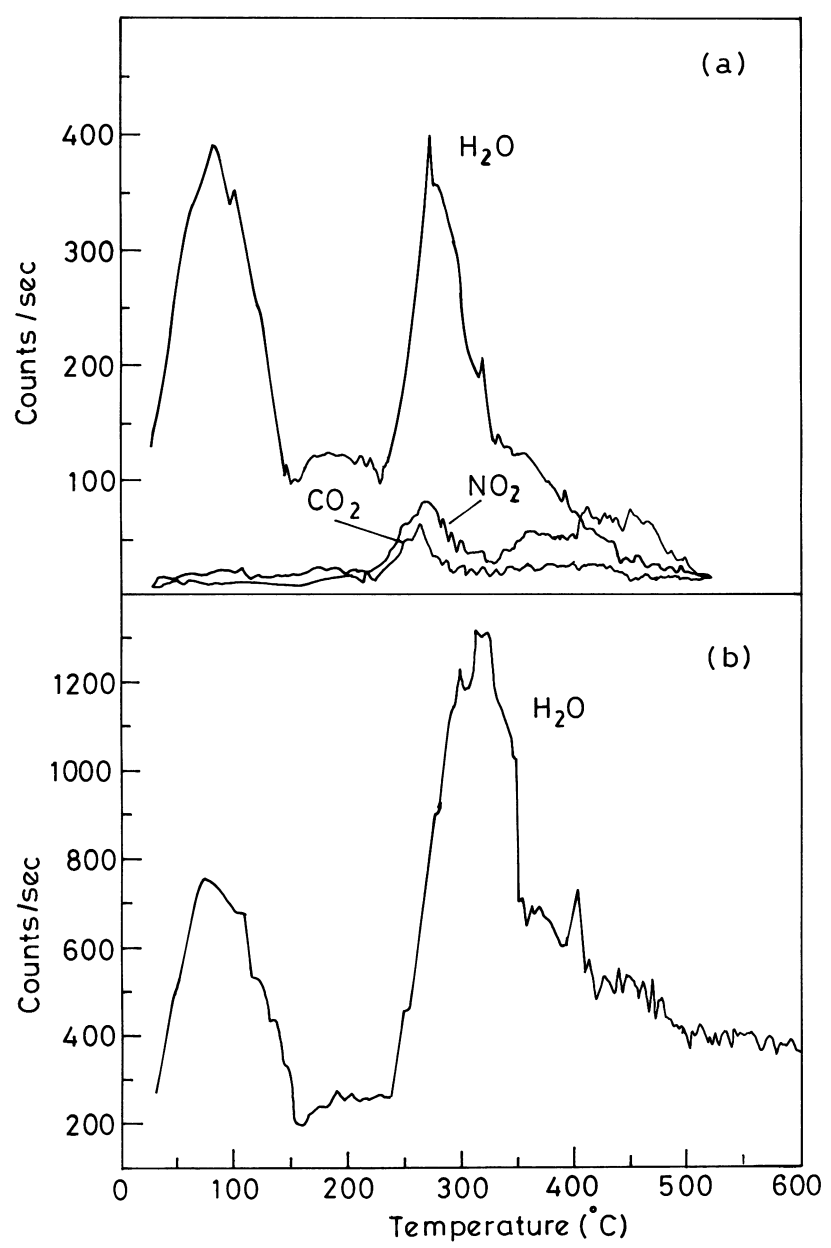

Figure 1. Temperature profiles of the gases evolved during the thermal decomposition of $\alpha$-nickel hydroxide (a) and $\beta$ nickel hydroxide (b). where $y=m-x / 2$ and suggested that $\mathrm{CO}_{2}$ is evolved in the first step due to the reaction

$$
\mathrm{CO}_{3}^{2-}+\mathrm{H}_{2} \mathrm{O} \rightarrow \mathrm{CO}_{2} \uparrow+2 \mathrm{OH}^{-}
$$

In order to understand which of these mechanisms is correct, we have carried out temperature programmed decomposition (TPD) of the title hydroxide materials coupled with mass spectrometric analysis of the evolved gases.

\section{Experimental}

$\beta$-Hydroxides of nickel and cobalt were obtained from Aldrich, USA. $\alpha$-Nickel hydroxide was prepared by cathodic deposition from a nickel nitrate solution (Jayashree and Kamath 1999a). $\alpha$-Cobalt hydroxide was prepared by

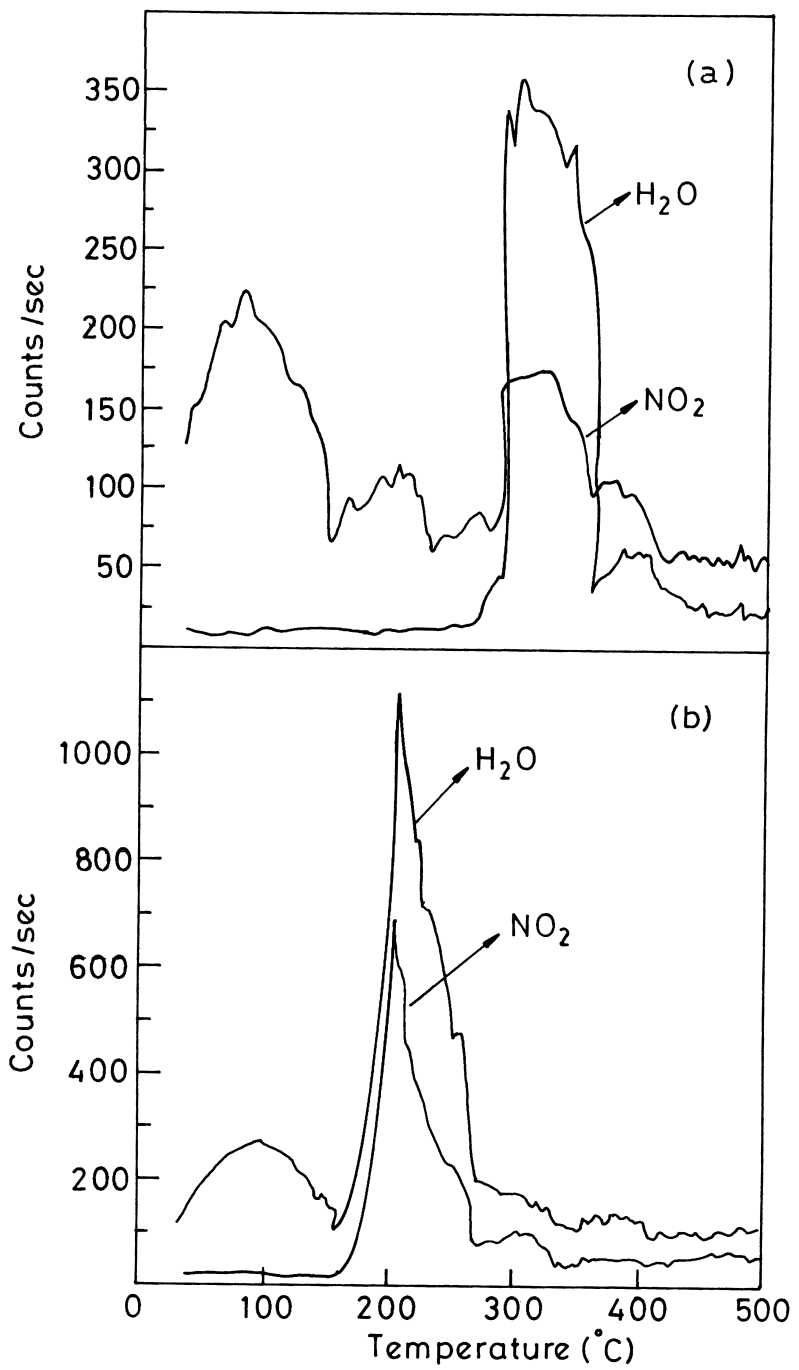

Figure 2. Temperature profiles of the gases evolved during the thermal decomposition of $\mathrm{Ni}_{3}(\mathrm{OH})_{4}\left(\mathrm{NO}_{3}\right)_{2}$ (a) and $\mathrm{Co}_{3}(\mathrm{OH})_{4}\left(\mathrm{NO}_{3}\right)_{2}(\mathbf{b})$. 
ammonia precipitation from a cobalt nitrate solution (Rajamathi et al 2000). The hydroxysalts, $\mathrm{Ni}_{3}(\mathrm{OH})_{4}\left(\mathrm{NO}_{3}\right)_{2}$ and $\mathrm{Co}_{3}(\mathrm{OH})_{4}\left(\mathrm{NO}_{3}\right)_{2}$, were obtained by urea hydrolysis of the corresponding metal nitrate melts (Rajamathi and Kamath 1998). Hydrotalcites, $\mathrm{Mg}_{1-x} \mathrm{Al}_{x}(\mathrm{OH})_{2}\left(\mathrm{CO}_{3}\right)_{x / 2} \cdot m \mathrm{H}_{2} \mathrm{O}, \quad(x=$ $0 \cdot 2,0 \cdot 25$ and $0 \cdot 33), \mathrm{Mg}_{1-x} \mathrm{Fe}_{x}(\mathrm{OH})_{2}\left(\mathrm{CO}_{3}\right)_{x / 2} \cdot m \mathrm{H}_{2} \mathrm{O}(x=0 \cdot 25)$, $\mathrm{Ni}_{1-x} \mathrm{M}_{x}(\mathrm{OH})_{2}\left(\mathrm{CO}_{3}\right)_{x / 2} \cdot m \mathrm{H}_{2} \mathrm{O} \quad(x=0 \cdot 25$ and $\mathrm{M}=\mathrm{Al}, \mathrm{Fe})$, $\mathrm{Co}_{1-x} \mathrm{Al}_{x}(\mathrm{OH})_{2}\left(\mathrm{CO}_{3}\right)_{x / 2} \cdot m \mathrm{H}_{2} \mathrm{O}(x=0 \cdot 25)$ and $\mathrm{Zn}_{1-x} \mathrm{Al}_{x}(\mathrm{OH})_{2}$ $\left(\mathrm{CO}_{3}\right)_{x / 2} \cdot m \mathrm{H}_{2} \mathrm{O} \quad(x=0 \cdot 33)$, were prepared by Reichle's (1986) method.

Materials were characterized by X-ray powder diffraction (JEOL JDP $8 \mathrm{X}$ Powder Diffractometer, CuK $\alpha$, $\lambda=1.541 \AA$ ), infrared spectroscopy (Nicolet Model Impact $400 \mathrm{D}$ FTIR, $\mathrm{KBr}$ pellets, $4 \mathrm{~cm}^{-1}$ resolution) and wet chemical analysis.

In a typical TPD experiment, about $0 \cdot 2 \mathrm{~g}$ of the sample was loaded into a quartz reaction tube in which a fine chromel-alumel thermocouple was immersed into the sample. The reaction tube was evacuated to a base pressure of $10^{-5}$ torr. The sample was heated from 30 to $750{ }^{\circ} \mathrm{C}$ at a heating rate of $10^{\circ} \mathrm{C} \mathrm{min}^{-1}$. The evolved gases were leaked into a ultrahigh vacuum chamber connected to a quadrupole mass spectrometer (Model QXK300, VG Scientific, England). The mass analysis was done every $10 \mathrm{~s}$ and the data stored in a computer. At the end of the experiment the temperature profile of the evolved gas was obtained from the raw data. The details of this laboratory- built TPD setup are described elsewhere (Hegde et al 1992).

\section{Results and discussions}

\subsection{Thermal behaviour of hydroxides}

In figure 1 are shown the temperature profiles of the gases evolved during the thermal decomposition of $\alpha$ and $\beta$ nickel hydroxides.

Stoichiometric $\beta-\mathrm{Ni}(\mathrm{OH})_{2}$ is expected to undergo a single step decomposition as

$$
\mathrm{Ni}(\mathrm{OH})_{2} \longrightarrow \mathrm{NiO}+\mathrm{H}_{2} \mathrm{O}
$$

Accordingly the mass spectrum of the gases evolved during the decomposition of $\beta-\mathrm{Ni}(\mathrm{OH})_{2}$ shows only the presence of $\mathrm{H}_{2} \mathrm{O}(m / e=18)$. The temperature profile of water evolved shows a decomposition range of 225$500^{\circ} \mathrm{C}$ and matches with the TG data (Jayashree and Kamath 1999b). $\alpha$-Nickel hydroxide on the other hand evolves both $\mathrm{H}_{2} \mathrm{O}$ and $\mathrm{NO}_{2}$ (appearing as $\mathrm{NO}, m / e=30$ ) on heating. Water is lost in two steps $\left(25-150^{\circ} \mathrm{C}\right.$ and $225-500^{\circ} \mathrm{C}$ ), while $\mathrm{NO}_{2}$ (along with trace $\mathrm{CO}_{2}$ ) is lost along with the high temperature $\mathrm{H}_{2} \mathrm{O}$ species. The low temperature water loss is shown to be reversible by TG

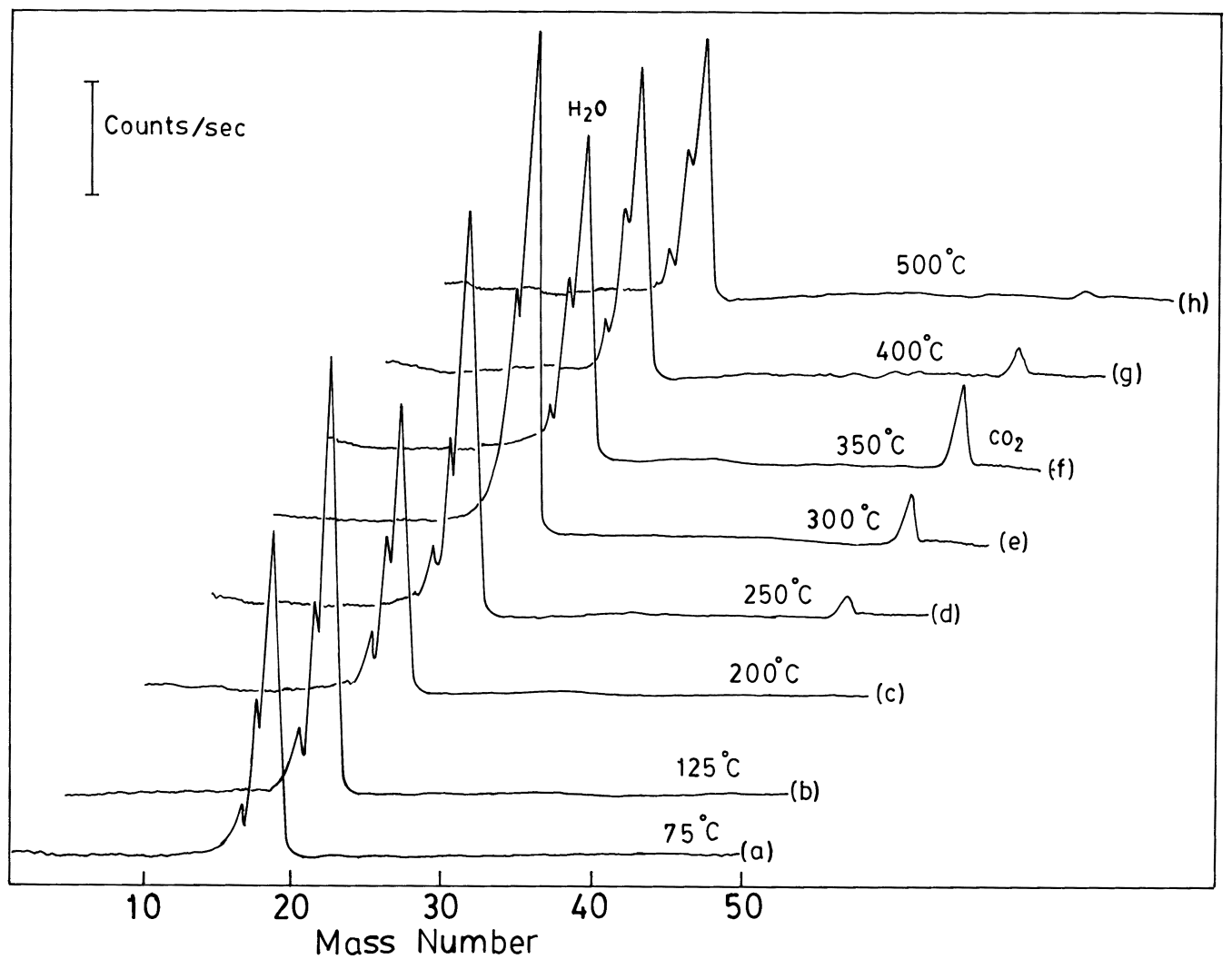

Figure 3. Mass spectra of the gases evolved at various temperatures during the TPD of $\mathrm{Mg}-\mathrm{Al}(x=0 \cdot 25)$ hydrotalcite. 
studies (Jayashree et al 2000). The sequence of reactions is dehydration followed by simultaneous deanationdehydroxylation.

$$
\begin{aligned}
& \mathrm{Ni}(\mathrm{OH})_{2-\mathrm{x}}\left(\mathrm{NO}_{3}\right)_{x} \cdot m \mathrm{H}_{2} \mathrm{O} \longrightarrow \mathrm{Ni}(\mathrm{OH})_{2-x}\left(\mathrm{NO}_{3}\right)_{x} \\
&+m \mathrm{H}_{2} \mathrm{O}, \\
& \mathrm{Ni}(\mathrm{OH})_{2-x}\left(\mathrm{NO}_{3}\right)_{x} \longrightarrow \mathrm{NiO}+x \mathrm{NO}_{2}+[(2-x) / 2] \mathrm{H}_{2} \mathrm{O} .
\end{aligned}
$$

$\alpha$ and $\beta$-Hydroxides of cobalt behave similarly except that they decompose at slightly lower temperatures and their decomposition product is the spinel, $\mathrm{Co}_{3} \mathrm{O}_{4}$.

\subsection{Thermal behaviour of hydroxysalts}

In figure 2 are shown the results of temperature programmed decomposition of the hydroxysalts, $\mathrm{M}_{3}(\mathrm{OH})_{4}$ $\left(\mathrm{NO}_{3}\right)_{2}(\mathrm{M}=\mathrm{Co}, \mathrm{Ni})$. TG data (Rajamathi and Kamath 1998, 1999) indicate that these decompose in a single step.

$$
\mathrm{Ni}_{3}(\mathrm{OH})_{4}\left(\mathrm{NO}_{3}\right)_{2} \longrightarrow 3 \mathrm{NiO}+2 \mathrm{NO}_{2}+4 \mathrm{H}_{2} \mathrm{O}
$$

Accordingly simultaneous loss of $\mathrm{H}_{2} \mathrm{O}$ and $\mathrm{NO}_{2}$ is observed in the temperature range $275-500^{\circ} \mathrm{C}$.

\subsection{Thermal behaviour of hydrotalcites}

Hydrotalcites are known to undergo a two-step weight loss on heating. The low temperature step $\left(25-220^{\circ} \mathrm{C}\right)$ has been attributed to loss of intercalated water molecules and the high temperature step $\left(225-450^{\circ} \mathrm{C}\right)$ has been attributed to decomposition (Constantino and Pinnavaia 1995). TG studies reported earlier (Puttaswamy and Kamath 1997) show that the hydrotalcites fall into three categories: (i) the hydrotalcites of $\mathrm{Mg}$ which show reversible thermal behaviour and reconstruct the parent phase even after the second weight loss, (ii) the hydrotalcites of Ni which show reversibility of the first step only and (iii) the hydrotalcites of $\mathrm{Co}$ and $\mathrm{Zn}$ which show a single irreversible weight loss.

Figure 3 shows the mass spectra of the evolved gases recorded at different temperatures during the TPD of the $\mathrm{Mg}-\mathrm{Al}$ hydrotalcite. It is evident that the only gases evolved during decomposition are $\mathrm{H}_{2} \mathrm{O}(m / e=18)$ and $\mathrm{CO}_{2}(m / e=44)$. The temperature profiles of $\mathrm{H}_{2} \mathrm{O}$ and $\mathrm{CO}_{2}$ evolution from the same compound are shown in figure 4. It is evident that up to $250^{\circ} \mathrm{C}$, the mass spectra indicate the evolution of only $\mathrm{H}_{2} \mathrm{O}$ showing that the Kanezaki phase II which is stable up to $260^{\circ} \mathrm{C}$ retains all the $\mathrm{CO}_{3}^{2-}$. $\mathrm{CO}_{2}$ evolution is observed along with additional water arising out of the dehydroxylation of the hydroxide sheets at temperatures in excess of $250^{\circ} \mathrm{C}$. All the hydrotalcites investigated by us showed similar characteristics and no $\mathrm{CO}_{2}$ evolution was seen in any of the samples at the

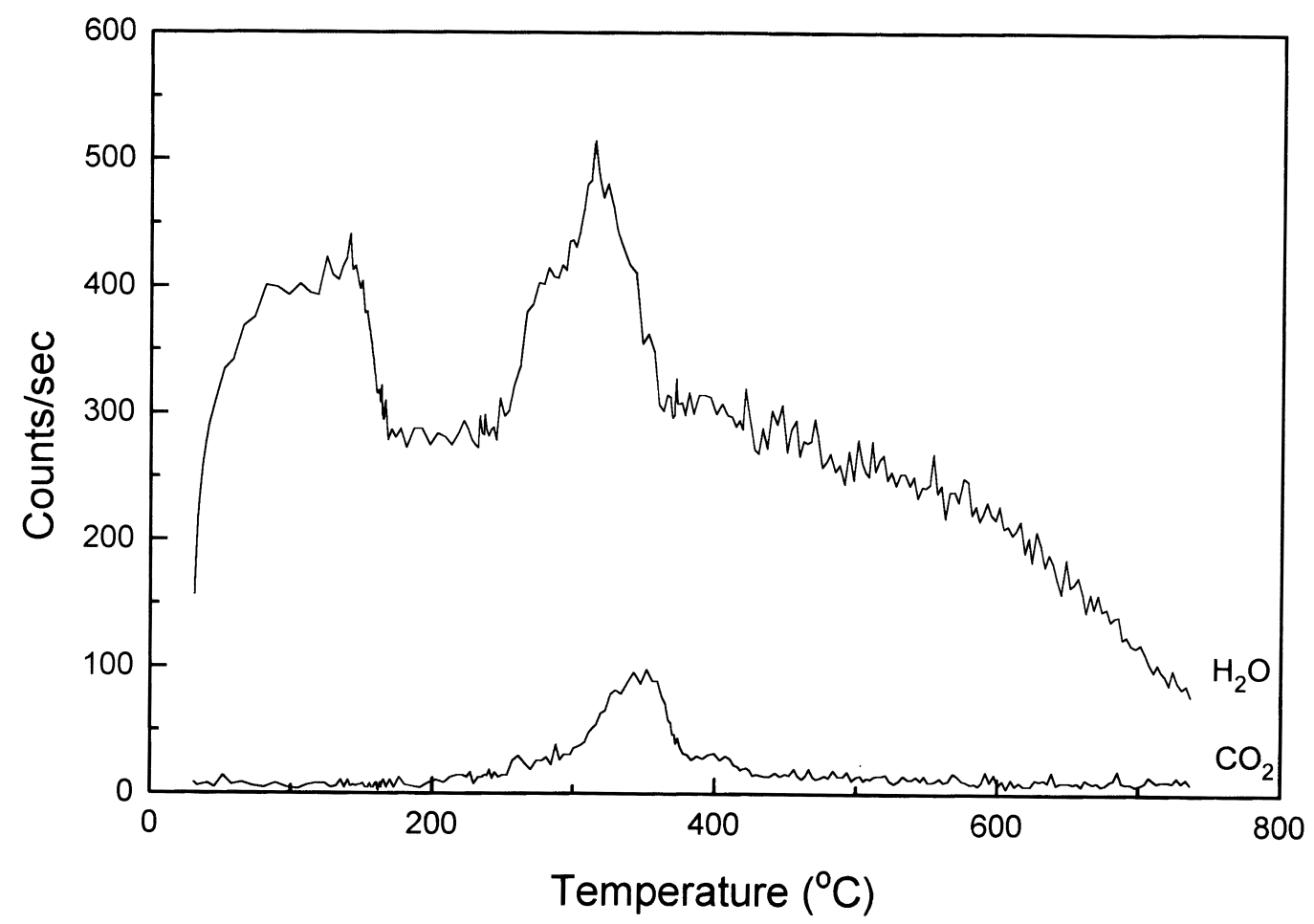

Figure 4. Temperature profiles of the gases evolved during the thermal decomposition of $\mathrm{Mg}-\mathrm{Al}(x=0 \cdot 25)$ hydrotalcite. 


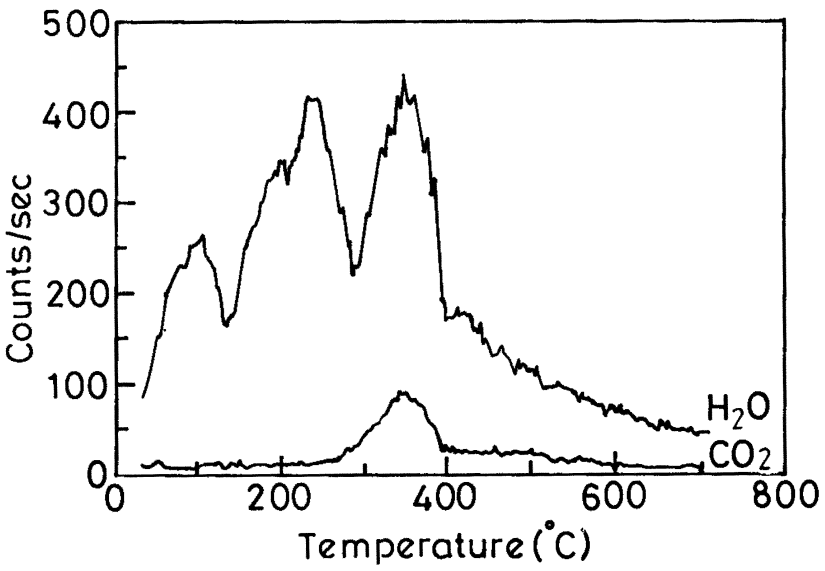

Figure 5. Temperature profiles of the gases evolved during the thermal decomposition of $\mathrm{Ni}-\mathrm{Al}(x=0 \cdot 25)$ hydrotalcite.

Table 1. Comparison of TG data with TPD data for hydrotalcites.

\begin{tabular}{lcc}
\hline $\begin{array}{l}\text { Hydrotalcite } \\
\text { (composition) }\end{array}$ & $T^{\circ} \mathrm{C}^{\mathrm{a}}$ & $T^{\circ} \mathrm{C}^{\mathrm{b}}$ \\
\hline $\mathrm{Mg} / \mathrm{Al}(x=0 \cdot 33)$ & 275 & 275 \\
$\mathrm{Mg} / \mathrm{Al}(x=0 \cdot 25)$ & 250 & 260 \\
$\mathrm{Mg} / \mathrm{Al}(x=0 \cdot 20)$ & 225 & 275 \\
$\mathrm{Mg} / \mathrm{Fe}(x=0 \cdot 25)$ & 225 & 300 \\
$\mathrm{Ni} / \mathrm{Al}(x=0 \cdot 25)$ & 245 & 275 \\
$\mathrm{Ni} / \mathrm{Fe}(x=0 \cdot 25)$ & 200 & 260 \\
$\mathrm{Co} / \mathrm{Al}(x=0 \cdot 25)$ & 180 & 250 \\
$\mathrm{Zn} / \mathrm{Al}(x=0 \cdot 33)$ & - & 200 \\
\hline
\end{tabular}

${ }^{\mathrm{a}}$ Temperature at which the first step ends in TG.

${ }^{\mathrm{b}}$ Temperature at which $\mathrm{CO}_{2}$ evolution begins in TPD.

temperature of the first weight loss. Another illustrative example is shown in figure 5 which corresponds to the $\mathrm{Ni}-\mathrm{Al}$ hydrotalcite. We list in table 1 the temperature at which the first weight loss (as obtained from TG data) (Puttaswamy and Kamath 1997) concludes and compare it with the temperature at which $\mathrm{CO}_{2}$ evolution begins in all the hydrotalcites studied here. It is evident that the $\mathrm{CO}_{2}$ evolution occurs only during the second step in all the cases. These results agree with the volumetric estimations of evolved $\mathrm{CO}_{2}$ performed by Hibino et al (1995).

\section{Conclusions}

We provide direct experimental evidence to show the Kanezaki mechanism of hydrotalcite decomposition inco- rrect and the widely accepted dehydration-decomposition mechanism correct. The mechanism of decomposition is the same in the related compounds, viz. hydroxides and hydroxysalts.

\section{Acknowledgement}

One of the authors (PVK) thanks the Department of Science and Technology, New Delhi, for financial support.

\section{References}

Baird T, Campbell K C, Holliman P J, Hoyle R W, Stirling D, Williams B P and Morris M 1997 J. Mater. Chem. 7319

Cavani F, Trifiro F and Vaccari A 1991 Catal. Today 11173

Constantino V R L and Pinnavaia T J 1995 Inorg. Chem. 34 883

Gallezot P and Prettre M 1969 Bull. Chim. Soc. (France) 407

Hegde M S, Ramesh S and Ramesh G S 1992 Proc. Indian Acad. Sci. (Chem. Sci.) $\mathbf{1 0 4} 591$

Hibino T, Yamashita Y, Kosuge K and Tsunashima A 1995 Clays Clay Miner. 43427

Jayashree R S and Kamath P V 1999a J. Appl. Electrochem. 29 449

Jayashree R S and Kamath P V 1999b J. Mater. Chem. 9961

Jayashree R S, Kamath P V and Subbanna G N 2000 J. Electrochem. Soc. (in print)

Kamath P V, Therese G H A and Gopalakrishnan J 1997 J. Solid State Chem. 12838

Kanezaki E 1998a Inorg. Chem. 372588

Kanezaki E 1998b Mater. Res. Bull. 33773

Kanezaki E 1998c J. Mater. Sci. Letts 17785

Kanezaki E 1998d Solid State Ionics 106279

Oswald H R and Asper R 1977 in Preparation and crystal growth of materials with layered structure (ed.) R M A Leith (Dordrecht: D Reidel)

Puttaswamy N S and Kamath P V 1997 J. Mater. Chem. 7 1941

Rajamathi M and Kamath P V 1998 J. Power Sources 70118

Rajamathi M and Kamath P V 1999 J. Mater. Chem. (submitted)

Rajamathi M, Kamath P V and Seshadri R 2000 Mater. Res. Bull. 35 (in print)

Reichle W T, Yang S Y and Everhardt D S 1986 J. Catal. 101 352

Sato T, Kato K, Endo T and Shimada M 1986 React. Solids 2 253 